\title{
AUTHORSHIP AND CULTURAL REVISIONISM IN PETER CAREY'S JACK MAGGS WITH SPECIAL REFERENCE TO DICKEN'S GREAT EXPECTATIONS
}

\section{Dr. Abd-El-Mageed Mohamed Khaled}

\begin{abstract}
The inventive energy of language and situation in Jack Maggs masks, but does not displace, the anxiety about the hazards of imaginative life, more specifically, about the role of narratives in understanding and conveying trauma. By turns comic, sad, and nightmarish,Jack Maggs follows its protagonist's dramatic journey in search of a place he can call home; through the "mutually reflexive acts of narrative and memory" (Olney xiv), home is redefined as both a point of departure and a point of return. The trajectory of Maggs's life intersects with that of novelist Tobias Oates, another strong-willed figure whose "crooked business," and the mind behind it,Carey investigates in an attempt to explain the birth of a book (Great Expectations) and the deathof a character (Abel Magwitch). Doubtless, the novel offers no conventional portrait of the artist as a young man. Since the author makes no claim to a "real life" basis for represent- ation, Oates's ortrait surprises, amuses, and provokes his readers. As a self-eflexive exercise in invention, Jack Maggs develops a great number of definitions for the writer: a storyteller, an archeologist of the mind, a mesmerist, magician,craftsman, and last, but not least, a "thief." To be a writer, Carey implies, is to have one's feet in both worlds - the public and the private, the actual and the imaginary, the material and the intellectual. Oates's professional life in the marketplace shapes his daily creative labours, which in turn reflect his desire to simultaneously confront and escape life's harsh realities.
\end{abstract}

Oates is, like Maggs, a restless soul hungry for love, but ultimately incapable of committing himself with heart and soul to anyone. He therefore reserves little sympathy for Maggs, who interests him more as a case study, than as a human being who embodies the dual capacities of man for good and evil. Maggs's "demons" originate not in the penal colonies, but in the very heart of the empire, which is London. Oates's excursion into the depths of Maggs's psyche leads him to proclaim "the horror" of the other, rather than the "saving illusion" of tolerance and compassion.

The analysis offered has led the researcher to a tantalizing conclusion: in reprising the past with a difference, postmodernism has also reappraised it so as to make it a precedent. Carey as a late twentieth-century writer has seized on the legacy of a canonical author to legitimize the origins of postmodernism, but in doing so he has also succeeded through cultural revisionism -in making that origin a source of his own originality. This technique allows us to see how postmodernism and the preceding "- isms" illuminate one another's forms, aesthetic strategies, cultural logics, or continued relevancies. From a broader perspective, the re-readings, revisions, and reevaluations take their place in the ongoing process of historicizing postmodernism. 
Peter Carey's engagement with Charles Dickens and Great Expectations in Jack Maggs (1997 bespeaks a contemporary sensibility, postmodern and postcolonial alike, that aligns it with recent revisions of canonical European texts by writers from the former British colonies in the period since 1945. One such text that comes immediately to mind is Jean Rhys's Wide Sargasso Sea, which retells Jane Eyre from the postcolonial perspective of the madwoman in the attic, thus drawing attention to the ways in which Charlotte Brontë's novel inscribes the discourse of empire. In composing Jack Maggs, Carey was motivated by a similar goal: to supply the suppressed point of view of Abel Magwitch, the transported convict and secret benefactor of Pip from Dickens's Great Expectations. As Carey maintained in an interview with Ramona Koval, "Dickens's classic text encourages you to "take the British point of view. And with that view, you love Pip, he's your person, and so suddenly Magwitch is this dark terrible other" (2). By shifting the focus from the Eurocentric to the antipodean perspective, from Pip (here Henry Phipps) to Magwitch (here Maggs), Carey allows for the colonized other to take control of his story, even as he is subject to the tales and inventions of others. The result is a profoundly sympathetic portrayal of a man who endures many hardships, first in England and then in the penal colony, at the hands of the British Crown, but manages to retain his humanity and regain a sense of belonging.

More than that, in Jack Maggs Carey takes the rewriting process one step further, for not only is he reimagining Dickens's fictional creation, but he also converts its author into a character, Tobias Oates, who is and is not Dickens. The story of Tobias Oates invites intriguing parallels with the documented biography of Dickens, which, as indicated in a note prefacing the novel, Carey takes the

\section{4}

J ournal of Arabic Studies in Education \& Psychology ( ASEP ) 
liberty to transform "to suit his own fictional ends." Carey confessed that because Dickens "knew the truth but distorted it," it took him "a long time to complicate that character and to stop being hard on him and to love him a little" (2). However, what is "the truth" that Carey is after, and exactly how did Dickens distort it? This question bears further scrutiny, especially in the light of the author's disclaimer quoted above and of the postmodern suspicion of truth, history, and objectivity.

As much as it harks back to Dickens and the carnivalesque world of his fiction, with its urban realism and interpenetration of competing discourses, Jack Maggs tells a distinct story: for, as Carey put it, "it is such an Aussie story that this person who has been brutalized by the British ruling class should then wish to have as his son an English gentleman, and that no matter what pains he has, what torture he has suffered, that would be what he would want." While hoping that this story reflects "the Australia of the past, not the Australia of the future," Carey also concedes the impossibility of fully knowing the past. His Dickensian pastiche feels to Carey like "a science fiction of the past in a way. None of us has been there. We have a lot of received opinion and it's intimidating to write because there are all these experts, but we don't really know" ("Interview" 2).

To be sure, Jack Maggs attests to the unflagging desire knowledge of the past that informs a late 20 century category of fiction known as the metahistorical novel, or to use a term coined by Amy J. Elias, the "metahistorical romance," in which the "virtuality" of the past accounts for the difficulty of recreating the emotional and psychological reality of another time. The conflation of personal memory and cultural consciousness forces readers to reconsider the meaning and significance of history, which, as Elias

\section{5}

J ournal of Arabic Studies in Education \& Psychology ( ASEP ) 
explains, for the postmodern, post-traumatic,metahistorical imagination, is "something we know we can't learn, something we can only desire (xviii).Although stylistically more conventional than other postmodern metahistorical texts, such as Julian Barnes's Flaubert's Parrot, Peter Ackroyd's Chatterton, or Jeanette Winterson's Sexing the Cherry, Jack Magg shares with these a treatment of the past as a textual construction under constant revision, scrutiny, and interrogation. Carey's novel, The History of Kelly Gang (2002), also about a convict in 19th century Australia, takes its epigraph from William Faulkner's Requiem for a Nun: "The past is not dead. It is not even past." This notion of continuity between the past and The present operates in Jack Maggs, where the narrative moves backward and forward in time, forcing us to examine the present in the light of the remembered past, and that past in the light of the present. Writing out of an antipodean consciousness, Carey insists that man can neither disavow the past nor evade the present, which carries within it not only the inescapable burden of the past but also the possibilities and responsibilities of the future.

Jack Maggs makes the reader acutely aware not only of the constructedness of the past, but of creativity as well, since the novel thematizes appropriation as its chief modus operandi.Within the novel's intertextual framework, neither Dickens's version of the convict's story, nor Maggs's own account of his experience of exile, nor certain biographical facts about Dickens himself can escape fictionalization. Both intertextuality and metafiction figure heavily in Jack Maggs, creating a narrative hybrid in which art spills over into life, fiction into history, to the point where they become almost indistinguishable, calling into question what ultimately comprises history. Like Dickens, Carey is a highly self-conscious, experimental writer who is stretching 
the range and power of the novel form to explore the increasingly complex sense of the self within the Victorian society.

In what follows, the researcher starts from the premise that Carey's dramatization of the workings of human consciousness and memory cannot be conceived apart from his inquiry into the practice and values of fiction making. The researcher remarks Carey's revisionist undertaking in Jack Maggs exposes the political and cultural stakes of an ideology of authorship that operated selectively, in complicity with the imperial ideology of his time, and in the service of both the "material interests and cultural capital of writers" (Deane 50). In order to explore the tensions inherent in Dickens's realist practice and in the construction of the authorial self, The researcher has found it useful to divide the essay into three sections, although they tend to overlap and merge into one another. First the researcher takes up a series of critical arguments that reconsider the traditional description of the realist novel as the chief agent of the moral imagination and implicitly the view of Dickens as a "sympathetic friend" (Deane xiii) to characters and readers alike. In Carey's novel, as we will see, Dickens's text seems to be a scientific compiler of facts about Jack Maggs, whom he regards as a case study, rather than a friend.Looking at Maggs, Oates reflects that he himself "would be the archeologist of this mystery; he would be the surgeon of his soul" (54). His anxious fascination with penetrating the "Criminal Mind" through mesmeric experiments is exposed as a bid for power instead of a means to make the other "less other," so to speak, by acknowledging his loss and suffering. Then the researcher turns to Maggs's personal history, which Carey intends for us to see as both the embodiment of the truth suppressed by Dickens's narrative and yet another interpretation of a

\section{7}

Journal of Arabic Studies in Education \& Psychology ( ASEP ) 
traumatic past. Finally, The researcher will probe the intersections between Oates and Dickens's life stories, and tease out the ethical and psychological ramifications of the "crooked business" in which Oates is embroiling Maggs.

\section{Dickens, Carey, and the Ethics of Storytelling}

From his early short stories to My Life as a Fake, Carey has demonstrated the power of words to name reality, to transfigure it, to alter consciousness, and to imprison it in the house of fiction. This interest in the deceptive as well as liberating power of storytelling Carey maintains throughout Jack Maggs, which can be read as a reflection upon the creative process itself and upon the rights and moral responsibilities of writers. Margaret Atwood confides that being a writer "is not always a particularly blissful or fortunate role to find yourself saddled with, and it comes with a price; though, like many roles, it can lend a certain kind of power to those who assume the costume" (5). But, she adds, "the costume varies," determined as it is by "other people's biases" about, or expectations of, writers. Dickens's wide popular appeal, however, seems to justify Nicola Bradbury's assertion that:

By accident and by design, Dickens effectively determined the shape, pace, structure, and texture of his own novel form, and developed both professional expectations of the writer and reader in the production and reception of his work. He made the novel what it was for the Victorians, creating and managing an appetite for fictions that would in turn make both imaginative and social demands. (152)

Dickens regarded literature as a noble and serious endeavour - "a perpetual struggle after an expression of the Truth, which is at once the pleasure and the pain in the lives

\section{8}

J ournal of Arabic Studies in Education \& Psychology ( ASEP ) 
of us workers of the arts" (qtd. in Lettis 95-96). What counts as truth for Dickens is not so much what is historically verifiable, but rather "what takes shape in the mind"- the use that the imagination makes of real- life experiences (Lettis 194). A remark that Dickens made about a prisoner entering jail, and that applieto Maggs too, suggests that reality, for the mind, is always in flux: "His [the prisoner's] confinement is a hideous vision; and his old life a reality." But as time passes, "the world without has come to be the vision, and this solitary life, the sad reality" (194). And so it is not the experience of the convict, but rather "the story about him," that creates truth for Dickens.By the same token, an accurate expression of this truth depends on one's willingness to "de-center," to enter other stories, however terrifying, and assume their perspectives. One can ask was: Dickens able to fully live up to this ideal, and, if not, what might account for his (partial) failure? Dickens was indeed able to create an enormous variety of characters, many of them are very different from himself, and to give a plausible account of their consciousness. Since a closer examination of Dickens's actual method of creating characters will be offered in another section of this essay, here The study will dwell on Dickens's characterization of Abel Magwitch and Carey's response to it.

Within Dickens's fiction we sense the driving force of a passionate, life-affirming energy, compounded equally of mind and body, of feeling and thought. John Bowen defines this ethical dimension of Dickens's writing in terms of an "opening to difference and to the other" that is not limited to compassion, that "does not eschew or fear emotion-no, not tears or rage, or anything" (30). Along the same lines, Grahame Smith claims that Dickens "could only have created Magwitch out of a love that enabled him to enter systematically into a life completely foreign to his own, at 
which he may just have glimpsed during the worst moments of the blacking factory episode" (6). The well-known "Autobiographical Fragment" written for John Forster in 1847 recounts Dickens's one-year (or nearly so) stint at Warren Blacking Factory, a shoe-polis warehouse, in 1824. This painful, humiliating episode had a lasting impact on Dickens's life and art, serving to explain the harsh view of parents that permeates his fiction and that was not lost on Carey. "As with other aspects of his personal experience," the episode is "objectified and transformed by Dickens into a comprehensive artistic vision of a parentless, above all, a fatherless, world" (6-7).

One of Dickens's famous statements concerning the blacking factory experience helps to explain his preoccupation with the themes of alienation and betrayal: "I do not write resentfully or angrily: for I know how all these things have worked together to make me what I am: but I never afterwards forgot, I never shall forget, I never can forget, that my mother was warm for my being sent back" (Forster I- 2). In Carey's novel, these themes resonate throughout Maggs's account of his childhood: the foster mother who criminalizes Maggs bears the name Ma Britten, an unmistakable variation on Mother Britain, the country that brutalizes and ultimately rejects Maggs as a delinquent other. As Maggs's employer, Percy Buckle, tells Oates in relation to his own sister who was also transported to Australia, "God help us all, that Mother England would do such a thing to one of her own" (89). Carey's novel makes irresponsible parenting symbolic of the lack of sustenance offered by the "mother country" to its dependencies.Like Dickens, Carey has invested his quirky, inventive fiction with an urgent moral purpose: "I have made a whole career out of making my anxieties get up and walk around, not only in my own mind but in the minds of readers" (qtd. in

\section{0}

Journal of Arabic Studies in Education \& Psychology ( ASEP ) 
Pierce 181-82). Carey also believes that a writer's responsibility is "to imagine what it is to be others. It's an act of empathy, and it's not only what we do, it's a socially useful act to imagine oneself to be other than one is" (qtd. in Koval).Hence, his passion for stating the case of the marginalized, which he does so compellingly in Jack Maggs, without lapsing into sentimentality.

Dickens's humane concern with the fate of the downtrodden cannot be questioned. His philanthropic activity, polemic journalism, speeches, and fiction, testify to his genuine interest in their suffering and to his "great desire," which "was not merely to communicate but to commune with his readers" (Lettis 141). Both the serialization of his work and the public readings late in his career kept Dickens closer to his readers, whom he addressed for more than just profit. "No one thinks first of Mr. Dickens as a writer," explained a critic in the North American Review," $\mathrm{He}$ is at once, through his books, a friend" (qtd. in Deane 28). Dickens's strong impact as a reader of his works has been compared to the influence exerted by the mesmeric operator on his subjects.Reaching out to his audiences, Fred Kaplan writes, Dickens was "like a mass mesmerizer, exploring and expanding himself through imposing himself and his own vision on others" (118). "Imposing" is a key word here, alerting us to the manipulative aspect of the writer's communicative process. If communication is one-sided, the desired communion with the audience would seem impossible to achieve.

Dickens's relationship to his audience was in fact as complicated as that to his characters and, more generally, to the society he lived in. As a man of his time, Dickens neither fought openly against society's conventions nor allowed himself to be mastered by them. Smith marshals

\section{1}

Journal of Arabic Studies in Education \& Psychology ( ASEP ) 
convincing evidence suggesting that, "Dickens came to see himself as peripheral" to the society whose abuses he relentlessly criticized, "although he continued to regard himself as of the center in relation to the ever increasing popular, if not always critical, appeal of his work." Wealth and fame aligned Dickens with the power structures, whereas his refusal to buy land apparently excluded him from these. His role as "an insider-outsider" to the economy of the empire links Dickens, on the one hand, with, Pip, the London gentleman, and, on the other, with Magwitch, the "black slave" of the English class system. More precisely, "the link between Magwitch and Dickens is clear, not only in their self-created riches, but in their ownership, the one of a "brought-up" gentleman, the other of a fictional character (Smith 51). Carey, we will see later, uses the trope of "ownership" to foreground the possession of secrets, in addition to wealth, as a determining factor in the power dynamics between the writer figure and the eponymous hero.

For Carey, as for other writers and critics, Dickens's interrogation of Englishness was undermined by his middleclass position. Without denying that "more than his predecessors and contemporaries in the English novel," Dickens strove "to give voice to the silent oppressed," Brian Cheadle observes that Dickens "was anything but a radical reformer, and in standing up for fellow-feeling and common humanity he looked to promote social change very much on middle-class terms" (103). Dickens's perception of colonial Australia reinforces this claim. Robert Hughes's impressive account of Australia's felon origins, and the "long" history of their "sublimation,"purports to show that

The idea of the 'convict stain' dominated all arguments about Australian selfhood by the 1840s

\section{2}

J ournal of Arabic Studies in Education \& Psychology ( ASEP ) 
and was the main rhetorical figure used in the movement to abolish transportation.Its leaders called for abolition, not in the name of an independent territory, but as Britons who felt their decency impugned by the survival of convictry. (xi-xii)

Dickens was among the reformers who opposed transportation on both moral and economic grounds. Along with journalist Samuel Sidney, philanthropist Caroline Chisholm, and writers Harriet Martineau and Edward Bulwer-Lytton, he shared the belief that Australia could become a "pastoral Arcadia" by way of yeoman emigration. This idealized view of life in the colonies ignored, however, the harsher realities of "drought, fire, and flood" that often confronted the farmers (Hughes 557-58). It also masked "the distaste verging on dread with which some middleclass Englishmen [Dickens included] viewed the transported convict 'making good' in exile" (585). Both these perceptions informed Dickens's ambivalent portrayal of Magwitch as a demonic figure bent on revenge, "capable of redemption" as long as he never returned to England. Suffering "warped" Magwitch — as it did other convictsinto a "permanent" outsider (586). Along the same lines, John Bayley, sees the terror the returned Magwitch unleashes in Pip as deriving from the fear of being possessed by another, and calls this "the direst threat Dickens's unconscious knows" (93). This certainly seems to be the case with Tobias Oates, whose fascination with the other's "Criminal Mind" turns gradually into fear and ultimately into repulsion.

It can be argued, of course, that such a warped view of the other, as well as the anxiety attendant upon it, was inescapable within the emerging capitalist system of Victorian England. Nor could it be resisted, except partially,

\section{3}

J ournal of Arabic Studies in Education \& Psychology ( ASEP ) 
given that "the racist inequities of the colonial periphery were inaccessible to metropolitan experience" (Cheadle 103). The reality of these contemporary ills looms large in Maggs's chronicle of his victimization, resurfacing during the hypnotic sessions orchestrated by Oates. To the extent that Carey's narrative is concerned with foregrounding this grim reality, with seeking out and articulating the repressed, its aim is to restore the truth, or at least test it through imaginative methods. As the arguments reviewed above indicate, this was a truth that Dickens may or may not have fully known, but that he too pursued. To put it in Elias's terms, the meta-historical consciousness in Carey's novel aligns itself with the consciousness of the Other, confronting the Self with the nightmare of history in which the Self too is implicated. At one point in the narrative, Maggs admits to a "strange thing": the "Phantom" that has been haunting his dreams was planted inside him by no one but Oates himself, who had claimed the power to be the "surgeon" of the convict's soul. A metaphor for the otherness embedded in the English psyche, the "Phantom" remains - for both Oates and Maggs - a terrifying presence up until the latter decides to leave England and return to New South Wales for good.Speaking of phantoms, in telling the story of a storythe writing of Great Expectations - Carey too is conjuring up ghosts - of the author, of his literary artifact, and of his characters - all made strange even as they seem familiar. In his will, Dickens implored - the actual verb he used is the archaic "conjure" - his friends "on no account to make me the subject of any monument, memorial, or testimonial whatever" (qtd. in Bowen 30). Writing is granted as "a free gift," for which remembrance is the only form of " repayment." This injunction, Bowen correctly remarks, places readers in "a double bind," as these are expected " both to memorialize and not to memorialize Dickens's

\section{4}

Journal of Arabic Studies in Education \& Psychology ( ASEP ) 
writing and name" (31). Jack Maggs registers the force and significance of Dickens's name and writing-Carey's indebtedness to Dickens - at the same time that it makes the latter responsible for a "debt" implicit in his distortion of the truth about Magwitch.

\section{The Purloined Story}

Jack Maggs is most impressive for its creative energy, which issues forth in the proliferation and interaction of story lines, modes, tones, styles, rhythms, and voices - all able to inscribe as well as challenge and destabilize different ideological positions. James Bradley has described the text's multi-layered structure as a "kind of fictional double gambit," in which "the story-telling process is twice internalized, by the novelist, Tobias Oates, and the narrator of the novel (or more accurately meta-novel)" (2). Among the novel's stories within stories, the most obvious are Maggs's own account of his victimization and Oates's drafts of his planned novel. In Jack Maggs Carey imagines the sources for novelist Tobias Oates's creation of his 1860 novel, The Death of Jack Maggs, which he abandons in 1837-the year when Oliver Twist was published - to take it up again in 1859. The fictive date of publication corresponds to that of Dickens's Great Expectations (serialized between 1860 and 1861 in All the Year Round).

Carey offers his readers a context drawn from Dickens's personal life as well as from early Victorian England-both intimately informing Dickens's work and art. London comes alive with the specificity of Dickens's own graphic evocation of the smells, textures, tastes, sounds, and feel of the metropolis, from its stylish houses to its back lanes and snuggeries. Carey's novel is more explicit, however, in its presentation of gritty details, of squalor and sexuality, than Dickens's. The narrative opens in April 1837,

\section{5}

J ournal of Arabic Studies in Education \& Psychology ( ASEP ) 
when Maggs, who had been deported as a criminal at an early age, returns to London in secret and at great risk, to seek out the son he adopted many years before. Like Magwitch, Maggs has devoted his life to raising a simple "orphing" out of poverty and into the life of a gentleman. Unlike Dickens, who leaves the source of Magwitch's fortune ambiguous, Carey makes it clear that Maggs's wealth was hard-won (the result of brick making). Finding Phipps's house empty, he takes employment next door in the household of Percy Buckle, a former grocer turned gentleman. During his first day as a footman, he is struck by an excruciating attack of pain, which one of the dinner guests, Tobias Oates, claims he can treat through animal magnetism.

In the person of Oates, Carey is giving us a glimpse of Dickens's younger self, as he is rising in his literary profession . Having earned a degree of fame as the inventor of "Captain Crumley" (a variation on Mr. Pickwick) and "Mrs. Morefallen," Oates channels his ambitions into a new project, a study of the Criminal Mind. Once introduced to Maggs, the novelist feels drawn to his mysterious mind, in which he suspects lies hidden a "world as rich as London itself. What a puzzle of life exists in the dark little lane-ways of this wretched soul, what stolen gold lies hidden in the vaults beneath his filthy streets" (90). Oates persuades Maggs to allow himself to be hypnotized by offering him a deal: if the writer can, through magnetism, "sketch the beast" within Maggs, he promises to introduce Maggs to the notorious "Thief-taker," who in turn can help him find his long lost son. From this point on, the relationship between these two "writer figures"-sodifferent in their cultural position, yet so similar in other respects - takes center stage.

The background Carey gives Maggs is strikingly similar to that of many Dickensian protagonists : orphan-

\section{6}


hood, poverty, dreadful labor, abandonment, betrayal, social humiliation, and oppression. Lonely and vulnerable, but defiant and resilient, Maggs immediately wins our sympathy: "I am an old dog . . . who has been treated bad, and has learned all sort of tricks he wishes he never had to know" (72-73). Maggs's self-characterization brings to mind Grahame Smith's point about Dickens's radicalism in his social and personal life. Much like Dickens, Maggs comes across as a man who, "rightly or wrongly, felt himself driven to desperate measures by desperate times" (Smith 15). Brutish and violent, Maggs is determined to put his life in order and record his own story, which he does by writing it backward in invisible ink. This peculiar method suggests his eagerness to simultaneously reveal and conceal his troubled past, just as he is torn between the compulsion to speak out and keep silent. "Even the lowest type of renegade," says Oates, "has an inner need to give up the truth. [...] It is what our fathers called 'conscience.' We all have it. For the criminal, it is like a passion to throw himself off a high place" (28). We will see that although driven by the same need, Oates is in fact hiding the truth about his private life under a respectable camouflage, and sees nothing wrong with twisting the truth that Maggs "gives up"during the mesmeric sessions.

Maggs's "high hope" is that the story he is so painstakingly transcribing will strike a sympathetic chord in Phipps, who will then accept Maggs for who he has become after his Australian sojourn: "I cannot bear him to think me a common criminal," he tells Oates (228). The letters fail, however, to move the young gentleman, who instead perceives them as "harbingers of destruction," a threat to his comfortable life. As it soon becomes clear, Phipps has no wish to meet Maggs, except to murder him in order to secure the house in Great Queen Street the latter provisioned from

\section{7}


afar. Weak, callous, and snobbish, Phipps eludes his benefactor's pursuit, just as the latter's dream of an idealized England becomes more and more elusive.

Jack Maggs is on many levels a novel of confinement, in which prison figures as an abusive enforcer of the law, as well as a complex metaphor for social relations and psychological life. The prison in New South Wales adds to other images of imprisonment that we encounter in the course of the novel, images that point, on the one hand, to Maggs' alienation from society and, on the other, to his struggle with himself. Maggs recalls that in his penitentiary, Silas had more freedom than he and Sophina did, continuing to "control much of our activity and to take, according to Tom, the lion's share of the profits" $(213,208)$. Maggs' and Sophina's confinement in the house of Ma Britten did not shelter them against dubious practices, for the rooms they were supposed to clean were those where Ma Britten performed abortions. While providing escape from such drudgery, the burglary expeditions only reinforced their imprisonment in the criminal life.

As the events unfold, it becomes less and less clear whether Maggs's criminality is inherent or the product of his environment. The question that the Judge asks of Sophina at the trial as imagined by Oates applies to Maggs too: "Do you mean that you are a thief by nature or a thief as evidenced by these charges?" (276). The criminal justice system uses these charges to demonize, dispossess, and dislocate Maggs, abandoning him to a strange land whose otherness Maggs comes to embody. This otherness is extremely unsettling, as it carries with it the memories and legacies of imperialism. Upon his return from the colony, the outcast brings with him the searing image of his brutal lashing by an officer of the Crown as well as two dark locks

\section{8}

J ournal of Arabic Studies in Education \& Psychology ( ASEP ) 
of hair belonging to the two sons of "Australian race."

Maggs's story presents a moving account of the convict's experience of exile in which he went with a soul steeped in history-personal and national-bearing in it many intertwined threads. Maggs is imprisoned not merely in the harsh reality of class and colonial exploitation, but also in a roseate fantasy of England Carey's metaphor for the human mind is the "tin box" in which Oates locks his characters' dark secrets that he extracts with his magnets and where Maggs keeps alive the Memory of "England's green and pleasant land" $(229,231)$. Despite the losses he sustained before his deportation, when he saw his 'brother' Tom betray Silas Smith and his childhood sweetheart sentenced to be hanged, Maggs is yearning for an England that is as much remembered as it is romanticized. All of Maggs's references to his native country have an elegiac tone associated with loss, distance, and nostalgia for vanishing beauty and innocence. Underneath "the scalding sun" at Morton Bay, he used to imagine:

the long mellow light of English summer, his mind, always, constructing piece by piece the place wherein his eyes had first opened, the home to which he would one day return, not the mudflats of the Thames, nor Mary Britten's meat-rich room at Pepper Alley Stairs, but rather a house in Kensington whose kind and beautiful interior he had entered by tumbling down a chimney, like a babe falling from the outer darkness into light. Clearing the soot from his eyes he had seen that which he later knew was meant by authors when they wrote of England, and of Englishmen.

Maggs's dream of England, together with the vividly recalled memories of his childhood and his youthful love for Sophina Smith, have sustained him in exile, offering solace

\section{9}

J ournal of Arabic Studies in Education \& Psychology ( ASEP ) 
to his traumatized consciousness. He passionately identifies himself with the country that expelled him and denies any ties with those of "that race," the "Australian race," as well as the freedom awaiting him there: "I'd rather be a bad smell here than a frigging rose in New South Wells" (230).

Because Phipps is a part of the English "family" to which he feels emotionally attached, Maggs persists in his love for his foster son at the expense of his own children back in Australia.He says that he determined to "weave [Phipps] a nest so strong that no one would ever hurt his goodness" (264). He carries with him the framed portrait of the four-year old boy who has kept him alive for the past twenty-five years. Through Phipps, Maggs lives out a compensatory and empowering dream on which he will not give up: "I am his da. He is my son. I will not abandon him" (264). This moving speech points, albeit obliquely, to the "Australian anxiety" that Peter Pierce explores in his book The Country of Lost Children, where he puts forth the "shocking"notion that "Australia is the place where the innocent young are most especially in jeopardy.Standing for boys and girls of European origin who strayed into the Australian bush, the lost child is an arresting figure in the history and the folklore of colonial Australia" (xi). Granted, Phipps has never been to Australia, but, as Pierce contends, the abiding force of the figure of the lost child has "deeper and darker origins and implications," standing for the generation of its parents, representing the anxieties of European settlers because of the ties with home which they have severed upon their arrival in Australia (x).

Such protection as Maggs wants for his son is ultimately impossible because of Phipps's own implication in the machinery of corruption. London to which Maggs returns is not different from London he grew up in-a

\section{0}


hellish place that breeds crime even in the innocent. As Oates recognizes, the miniature Phipps sent to Maggs is a portrait of King George IV; interestingly enough, the Phantom haunting Maggs's dreams also appears dressed as a soldier (Captain Logan) of the $57^{\text {th }}$ Regiment who flogged Jack when he was a convict at Morton Bay. It is not coincidence that Phipps has joined the same regiment. At one point, Maggs tells Mercy that he was flogged by a "soldier of the King," to which the maid replies, "Then it were the King who lashed you" (318). This insight is both devastating and liberating for Maggs, who finds his dreams shattered, yet his dignity and peace of mind restored.

As Anthony Hassall points out, the recognition also releases Phipps from the "the script" his benefactor had "written for him into his own life and his preferred sexuality" (4). For years, he has been living a lie, perpetrated by his replies to Maggs's letters:

He had known this time would come ever since that day sixteen years ago when Victor Littlehales, his beloved tutor, had rescued him from his orphanage. Now this privileged tenure was ended and he must leave his house, his silver, his rugs, his paintings. He must be a soldier. (Carey 4)

Thus, the final confrontation between the soldier and his benefactor suggests that neither "can escape without violence from the fictions which have structured their lives" (Hassall 5).

Implicit in the false ideal Maggs constructs for Phipps is the desire for revenge on the genteel society that ostracized and vilified Maggs. As in Magwitch's case, Maggs's generosity to Phipps is meant to show that respectability is for sale - merely another fiction. Echoing

\section{1}

Journal of Arabic Studies in Education \& Psychology ( ASEP ) 
Hughes, Bradley notes that in Phipps, Maggs "has created a gentleman of his own, a living [Hughes calls it "black"] joke at the expense of the country and class that has ruined him" (3). But Maggs cannot escape fictionalization either, for not only does he become a subject of stories circulated in both the Oates household and the house in Great Queen Street where he passes himself off as a footman, but his life story is being appropriated by Oates as raw material for one of his novels. With the exception of Mercy, all the other characters stereotype Maggs in terms that reflect what Hughes refers to as the myth of the "geographical unconscious"; ironically, the same spatial metaphor figures in Oates's own comparison of the Criminal Mind to London itself. "So," Hughes concludes,"there was a deep ironic resonance in the way the British, having brought the Pacific at last into the realm of English consciousness, having explored and mapped it, promptly demonized Australia once more by chaining the criminals on its innocent dry coast. It was to become the continent of $\sin "(44)$.

It is this notion of the convict as a bearer of sin that Dickens apparently emphasized, and that Carey sets out to revise by presenting Maggs as more sinned against than sinning - a brutalized man, yet "full of love." The trials and tribulations that the convict had to suffer did not end after he had expiated his crime; indeed, the cruelties inflicted by the English have left physical as well as psychological scars that cannot and should not be ignored: "It would not have been lost on [Oates] that Mercy Larkin's wedding finger was blown away, and that when Jack Maggs came to her side, the pair were finally matched in deformity" (327). The twin deformities imply that Maggs's sense of identity is intimately bound up with both England and Australia, though he finally embraces the more tolerant and hospitable culture of the latter. In the tersely narrated climax, Mercy

\section{2}

Journal of Arabic Studies in Education \& Psychology ( ASEP ) 
alerts Maggs to the danger of deluding himself into thinking that Phipps is a "better class of son" (318), by which he would do to his own children what England did to him. Having awakened Maggs from his somnambulistic dream, helped him overcome alienation, and even risked her own life to save his, Mercy earns the right to become his wife and the guardian of his legacy. Together Mercy and Maggs return to the New South Wales colony, where Maggs lives a long and prosperous life, respected by the community and loved by his family.

The ending that novelist Tobias Oates has in store for Maggs is different, however, than the one envisaged by Carey. When filtered through Oates's hungry, but largely unsympathetic imagination, Maggs's life story follows a much darker course, as suggested by the title of his planned novel, The Death of Maggs. In Tobias Oates, Carey offers readers an intimate, far from flattering, portrait of Dickens as a young man and as the creator of Abel Magwitch. It is to this fictional portrait that the researcher will turn my attention next. In revisiting some of the issues explored in the first section of this essay, the researcher will argue that Carey's dramatization of the novelist's "crooked business" poignantly sets forth the moral implications of the process by which novelists create characters and use their imagination to enhance, if not reshape reality. In the context of Carey's own recreation of one of Dickens's fictional characters, the word reality should, of course, be enclosed within quotation marks. But even though as a postmodernist Carey questions the possibility of any solid reality behind the discourse of representation, as a postcolonial writer, he never questions the emotional impact, the felt truth, of stories such as Magg's in which great expectations - in this case, self-definition and self-assertion - are finally realized.

\section{3}

J ournal of Arabic Studies in Education \& Psychology ( ASEP ) 


\section{The Storyteller and His "Crooked Business"}

"There were, as in all crooked businesses, two sets of books, and had Jack Maggs seen the second set he might have recognized scenes (or fragments) more familiar to him: a corner of a house by London Bridge, a trampled body in a penal colony. But even here the scenes were never clear. For the writer was stumbling through the dark of the convict's past, groping in the shadows, describing what was often a mirror held up to his own turbulent and fearful soul." (Carey 91)

A complex tribute to England's great novelist, Carey's meta-narrative bears out the truth of John O. Jordan's statement, according to which Dickens is "also a living and ever-changing text, as important to late twentieth-century writers in the Anglophone Diaspora as he has always been for those closer to the metropolitan centers" (249). Jordan's essay focuses on postcolonial works that feature intertextual references to Dickens, such as V.S. Naipaul's A House for Mr. Biswas (1961), and on more extended instances of Dickensian intertextuality, like David Allen's play, Modest Expectations(1990), Frederick Busch's novel The Mutual Friend (1978), and Salman Rushdie's The Satanic Verses (1988). Versions of Dickens that emerge from these works resurface in Jack Maggs, most notably, " Dickens the magical realist, haunted by scenes of violence and grotesque comedy" and "Dickens the verbal fantasist, creating the world out of language" (242). What really captivated Carey's imagination, however, was "the notion of the writer raiding, burgling the soul of his subject" ("Interview" 3). And since Jack Maggs is telling his story himself, the image of the writer as a thief is juxtaposed with that of "the thief as a writer." As their stories unfold against London's dismal background, these characters' destinies intertwine,

\section{4}

J ournal of Arabic Studies in Education \& Psychology ( ASEP ) 
generating the tension that provides the novel's compelling dramatic structure and enriching its tapestry of fact and fiction.

Jack Maggs is not really a novel about Tobias Oates, or even about its eponymous hero, so much as it is a novel in which these characters reveal themselves to us in all their complexity through flashbacks, action, and interaction. The novel relies on the readers' familiarity with both Dickens's Great Expectations and some key events from his biography that illuminate the novelist's particular sensibility. This intricate tangle of references and cross-references aligns Jack Maggswith other postmodern interrogations of the relationship between fact and fiction, life and work, memory and imagination. More specifically, as demonstrated below, the "crooked business" in which Tobias Oates embroils Jack Maggs sends a cautionary message about the lengths to which writers can go in their attempt to carve out a name for themselves. Atwood's warning, that writers "can be accused of appropriating the voices of others," of exploiting the misery and misfortune of the downtrodden for [their] own gain" (119), bears directly on Oates's method of character making in Jack Maggs. The novel invites us to consider the question of an author's "dominion over and answerability to the personae he has called into being" (Steiner 42). "Is that dominion," George Steiner asks, "boundless or do the 'creatures' have certain rights in respect of their creator?" (42). Seen in this light, Carey's project is to restore Magwitch's claim to his inviolate inwardness, his right as a "creature" whose past, present, and future, are on a symbolic level, entangled with the history of Carey's own country. He thus indirectly holds Dickens accountable for having trampled on this particular character's freedom. At the same time, Carey reminds us that "theft"-in the sense of textual and cultural appro-

\section{5}

J ournal of Arabic Studies in Education \& Psychology ( ASEP ) 
priation-plays an inevitable part in the creative and transformative process.

Part of Dickens's appeal for Carey concerns, on the one hand, with his social, financial, and emotional insecurities, and, on the other, with his restless energy and ambition-his eager determination to succeed: "Having come from no proper family himself, or none that he could remember without great bitterness, he [Oates] had for all his short, determined life carried with him a mighty passion to create that safe warm world he had been denied" (36). Carey intentionally stresses Oates's resemblance to his literary forebear-and to Jack Maggs as well-by delineating his humble beginnings and trying personal circumstances . Oates recalls how he was "forced tomake his own way" in the world, "to find his feet in a city that would as soon trampled him into the mud." An autodidact, Oates "had made himself, by will, a sorcerer of that great city " (184). Like Dickens, Oates makes his living by writing character sketches and little vignettes of London life for the Morning Chronicle and the Observer. His first achievement as a professional novelist was the tale of Captain Crumley, which parallels the launching of Dickens's own career with the successful serialization of The Pickwick Papers (1837).

The emotional deprivations of his childhood-the feelings of neglect and abandonment-left indelible scars on Dickens's consciousness and fueled an irrepressible desire to be loved. Tobias Oates also fears that "he would not be loved enough, not ever" (37). He assures Maggs that it is not hard for him to understand his feelings, for he too has a son upon whom he dotes, "as his father had never doted on him." And because he would not have his son grow up in dreariness, or darkness," Oates has built a relatively safe haven for him, filling his house with "books

\section{6}

Journal of Arabic Studies in Education \& Psychology ( ASEP ) 
and laughter," with "colorful rugs" and mirrors, "these last being desired for their light" (37) as well as, we suspect, for their distorting effect. This overprotective impulse, we recall, was equally strong in Maggs, who would keep Phipps, as he remembered him from years before, out of harm's way.

Where both Maggs and Oates are concerned, emotional dysfunction stems primarily from a lack of proper father images. Oates suffers the same stigmas that Dickens felt in relation to his father, whose financia 1 difficulties led to his imprisonment for debt. Oates tells Mary, his wife: "My father will tell any untruth to get his hands on money" (117). But he should plead guilty to the same charge, for the deal he has cut with Maggs entails just that: telling "untruths" so that he can pay his own debts. He is in fact very confident that "[m]oney will come of it" (118). The fact that Oates sells the copyright of The Death of Maggs even before he has written the novel brings into focus the mercantile motif which governs both the economic and social worlds of the novel. As evidenced by the calculations in the margins of his manuscripts, "[m]oney was a subject always on his mind" (129). In only "five minutes," Oates writes his father a "painful letter" disclaiming further responsibility for his debts, but then it takes him almost half an hour "composing a more cautious public announcement to the same effect" (177).

Oates's deeply ambivalent attitude toward his father, while subtly mirroring that of Carey towards Dickens (his literary father), serves to explain why Oates felt compelled to turn his energy from private to public life, and from actuality to fiction. His "strongest impulse was to go where he most feared the deluge would sweep him" (197). When Oates was five years old, his father was charged with killing

\section{7}


a man in a tavern brawl, for which he was tried at Old Bailey and condemned to death by hanging. "Toby's earliest memories of London were still locked in that fetid little death cell, where his father sat writing, day and night, getting up petitions for his pardon" (196). From his father, Oates "inherited his habit of confronting what he feared," a habit that fed into his writing:"He feared poverty; he wrote passionately about the poor. He had nightmares about hanging; he sought out executions, reporting them with a magistrate's detachment." Although Oates prides himself on his detachment, he has difficulty maintaining it. For direct exposure to the desperate conditions the writer has reported on has only "magnified" his fear of eventually drowning himself and his family into "such purgatory" (198).

Dickens's domestic misery finds its way, much disguised, into the main subplot of Oates's ill-fated marriage to Mary and his self-indulgent love for her sister, Lizzie Wariner. Unlike Mary, who "had little patience for either science or literature" and did not value her husband's genius highly (82), Lizzie looks up to Oates and understands his intellectual aspirations, even as she sees through all the tricks of his "trade" (art). Their liaison has disastrous consequences - the wasting of Lizzie's young life and the poisoning of his marriage - that Oates realizes only too late. The date of Lizzie's death (May 7, 1837) corresponds to the date on which Dickens's sister-in-law Mary Hogarth died in his arms, a loss that affected him deeply and colored his fictional representations of young women. It has been speculated that Dickens felt a paternal love for Mary Hogarth, in whom he saw a symbol of all the innocent qualities he loved about childhood. He cut off a lock of her hair, took a ring from her finger, and kept all her clothes. He even requested that he be buried next to her when he died (Ackroyd 115). ${ }^{7}$ Dickens did become involved

\section{8}


in a liaison with actress Ellen Ternan, for whom he eventually left his wife, in 1858 . The rumors caused by the failure of his marriage troubled Dickens who, in the public mind, had until then been associated with family values.

In Jack Maggs, Oates also feels a tug of guilt and shame for the betrayal he has committed and ponders the dreadful consequences of public disclosure: "Yet once it was known that he had betrayed his wife and ruined her young sister, who would ever wish to touch a book with his name upon its spine?" (198). Hiding his doubts and unfulfilled longing beneath a veneer of popular success, the young novelist " invented a respectable life for himself : a wife, a babe, a household" (182). This precarious respectability, we will see shortly, makes Oates as vulnerable to life's blows as Maggs. To the latter's mind the writer did not seem "to warrant any of the excitement his name had stirred in Mercy Larkin's imagination" (26). To Lizzie, Oates had always appeared "as fierce and fatherly, but now she saw how the mantel was too tall for him, and how he stretched to accommodate to its demands. It was a vision most profoundly discouraging, and one she wished to God she had not seen" (196). In cutting Oates down to human dimensions, Carey underscores his likeness to others and suggests that learning to accept one's humanity may be as valuable as one's art. Oates has yet to learn what Dickens learnt, namely, that a mature artistic vision entails a compassionate understanding of fellow humans.

So far the study has stressed two aspects of Dickens's appeal to Carey-his wrestling with personal demons and his craving for love - as they carry over into the subplot about Tobias Oates's domestic life. In the remainder of this study, the researcher focuses on Oates as both an embodiment of the artistic temperament in general, committed to

\section{9}

Journal of Arabic Studies in Education \& Psychology ( ASEP ) 
an understanding of fiction as the artificial shaping of life, and as the practitioner of an art whose nature is exposed as morally questionable,or crooked, and therefore dangerous.

In his interview with Ramona Koval, Carey mentions that he discovered in his reading about Dickens that the latter was a passionate mesmerist who treated a woman called Madame Emile de la Rue for her condition called tic douloureux, an acute pain in the face. Indeed, widely read and self-taught in various subjects, Dickens followed with much interest the emergence of mesmerism, physiognomy and phrenology, all new sciences that offered different forms of investigating the hidden mind and cures for plagues of the nervous system.Mesmerism nurtured Dickens's novelistic imagination by providing him with a vehicle for exploring the human self, the origins and nature of evil, the nature and influence of power relationships between people, the uses of energy and will, reality and dreams, etc. His major experience as a mesmerist, which was strongly to influence his life and his fiction, took place in 1843, in Italy, where he met Madame de la Rue.

Several biographers-among them Johnson (541-42), Ackroyd (449-52), and Kaplan record that Madame de la Rue believed she was pursued by a phantom, a "bad spirit," which Dickens perceived as "intimately connected with the hidden pains and anxieties of her being" (Kaplan 86). As Kaplan observes, Dickens's speculations on the origins of the Phantom - the notion that his patient's nervous disease was " itself attacked by the inexplicable agony of the magnetism" - demonstrate " the psychological perceptiveness of Dickens the novelist, who frequently used some symbolic projection of the inner life and the imagination to represent a central illness of the spirit" (85-86). In his determination to " imprison or destroy the evil force,"

\section{0}

Journal of Arabic Studies in Education \& Psychology ( ASEP ) 
Dickens himself " became a surrogate for the patient, internalized her struggles, and took the Phantom as his personal enemy." Dickens feared that the power of the Phantom might reassert itself and take "horrible revenge" not only upon Madame de la Rue but on him as well "unless she gave up the mesmeric treatments" (qtd. in Kaplan 8788). Even more remarkably, he developed an anxiety concerning her being "somehow a part of me," implying that his "patient" and her Phantom were "extensions of him" (qtd. in Kaplan 89-90). Hence the possibility that Dickens "recognized" his own "strange afflictions" in Madame de la Rue's (159).

The researcher has dwelled on Kaplan's account of Dickens's involvement with Madame de la Rue's case because similar transferences occur between the mesmerist and his patient during their sessions together in Jack Maggs. To dramatize the parasitic relationship between the two, Carey draws heavily on the language and imagery of mesmerism that Dickens himself used both in his journal and fiction. Thus not only does he have Maggs suffer from the same physical pain as Madame de la Rue, but he also shows Oates attempting to cure this condition-along with its mental cause (the psychic trauma) - through what he calls "magnetic somnambulism" (27). Maggs exemplifies for Oates the mystery of psychological forces whose attraction the young novelist, much like Dickens, finds irresistible: "When he entered the soul of Jack Maggs, it was as if he had entered the guts of a huge and haunted engine. He might not yet know where he was, or what he knew, but he felt the power of that troubled mind like a great wind rushing through a broken window pane" (58). "He cannot help himself," one of Oates's servants tells Jack, explaining:

\section{1}

Journal of Arabic Studies in Education \& Psychology ( ASEP) 
The researcher has dwelled on Kaplan's account of Dickens's involvement with Madame de la Rue's case because similar transferences occur between the mesmerist and his patient during their sessions together in Jack Maggs. To dramatize the parasitic relationship between the two, Carey draws heavily on the language and imagery of mesmerism that Dickens himself used both in his journal and fiction. Thus not only does he have Maggs suffer from the same physical pain as Madame de la Rue, but he also shows Oates attempting to cure this condition-along with its mental cause (the psychic trauma)-through what he calls "magnetic somnambulism" (27). Maggs exemplifies for Oates the mystery of psychological forces whose attraction the young novelist, much like Dickens, finds irresistible: "When he entered the soul of Jack Maggs, it was as if he had entered the guts of a huge and haunted engine. He might not yet know where he was, or what he knew, but he felt the power of that troubled mind like a great wind rushing through a broken window pane" (58). "He cannot help himself," one of Oates's servants tells Jack, explaining : He saw your livery, and thought: There's a chap with dirty livery. Just what you would think or I would think, but Mr. Oates, he can't stop there he's thinking, how did that fatty-spot get on his shoulder? He's wondering, in what circumstances were the stockings torn? He's looking at you like a blessed butterfly he has to pin down on his board. It is not that he hasn't got a heart. But he is an author, as I'm sure you don't need telling, and hemust know your whole life story or he will die of it. (42)

These quotations vividly set forth the illuminating connection between the concerns about the workings of the hidden mind raised by mesmerism and the fascination with the process of creating character, a process driven by intuition as much as it is by conscious intent.

\section{2}

J ournal of Arabic Studies in Education \& Psychology ( ASEP ) 
Oates's imaginative insight into criminal psychology, his versatile journalism, and his familiarity with court proceedings-all bring to mind Dickens and his peculiar method of collecting characters based on real-life criminals. Lizzie reflects that "Toby had always had a great affection for Characters," i.e. "dustmen, jugglers, costers, pickpockets," whose histories he writes down in his chapbook. From the narrator, we learn that Oates has "much of the scientist" about him. His study is as methodically ordered as a laboratory, with everything neatly categorized and labeled. In its corners Oates "stored not only his Evidence, but also experiments, sketches, notes, his workings-up of the characters who he hoped would one day make his name, not just as the author of comic adventures, but as a novelist who might topple Thackeray himself" (44). Relishing his role as the "first cartographer" of the Criminal Mind (90), Oates "blithely" likens himself to Thackeray, whose success he is eager to emulate (91).

In Jack Maggs, however, the writer laughing at the follies of others becomes himself a target of satire because of the scientific pretensions underpinning his method of creating characters.As indifferent to her husband's artistic pursuits as Mary might be, she cannot help wondering why, in approaching his new subject (Maggs), he is no longer solely relying on his imagination: "You never needed magnets before. You used an ink and pen. You made it up, Toby. Lord, look at the people you made. Mrs. Morefallen. Did you need magnets to dream her up?" (118) But for Oates, as for Dickens, mesmerism was "an example of the inventive process of the imagination" (Kaplan 90). Unlike Dickens, however, according to whom "most writers of fiction write partly from their experience,and partly from their imagination," (qtd. in Lettis 187), Oates maintains that his business is "to imagine everything" (88). So inflamed

\section{3}


does his imagination become with the possibilities of peering into Maggs's soul that it preempts the subject's lived experiences.

By deliberately neglecting the demands of verisimilitude, Oates is highlighting certain aspects of Maggs's personal history, while obscuring others. Trapped as he is inside his own mind, in the mental chains of snobbery and pretentiousness, the writer fails, or simply refuses to see, that this history takes deep roots in both the culture of the colonized and that of the colonizer. His presumption of omniscience- "I got the rascal" (86), he triumphantly announces to Buckle - is thus deep especially when suspect once we realize that he ends up writing about Maggs whom he has "dreamed up." Consequently, after reading the drafts of the novel which is supposedly about him, Maggs confronts the author with the fact that he actually understands "nothing" about him: "You can hoodwink me into taking off my shirt, but you don't know a rat's fart about me ... You steal my Fluid but you can't imagine who I am, you little fribble" (252).

The novel can then be read as a cautionary tale about the limitations of imaginative life, with Maggs embodying a mystery that, because it cannot be imaginatively fathomed, stands outside representation. This mystery, Carey seems to imply, can only be approached with the heart, not with the mind; in the absence of absolute truths, the only truth worth searching for is compassion. Maggs, we have seen, finds it thanks to Mercy, the young Englishwoman with a great capacity to heal and love. But Oates, who is writing about Maggs and pretending to know his innermost thoughts and feelings, must also be willing to respond to him with the fullest extent of his humanity. As Richard Holmes so wonderfully puts it, "To find your subject, you must in

\section{4}

J ournal of Arabic Studies in Education \& Psychology ( ASEP ) 
some sense lose yourself along the way, [you must] stray into the geography of the human heart" (iv).

In the first section of this study, the researcher showed that Dickens possessed this capacity for interacting, even identifying with, rather than simply reacting to his subject matter. His preface to A Tale of Two Cities ensures his readers that, "I have so far verified what is done and suffered in these pages, as that I have certainly done and suffered it myself" (7). Here Dickens suggests that his work does equal justice to external and internal reality, to the world the author inhabits and to his experience of that world. We are also led to believe that his characters and situations evolved out of the depths of his consciousness, although he typically began with his experience of real people and then brought his creative imagination to bear on it. Describing Dickens's essentially dramatic method of creating characters, Lettis has argued that the novelist "did not care for psychological fiction: it was the secret processes not of the mind but of the heart that he thought fiction should seek out" (61). But the first part of this statement overlooks Dickens's interest in "the multi-layered psychological and ideological complexities" of mesmerism, the extent to which it is enmeshed in issues of power, energy, and will - three concerns that pose moral questions in that they are "potentially both destructive and constructive" (Kaplan 9, 19).

In Jack Maggs, Oates's engagement in such an exercise of both power and will shows little regard for moral considerations, although claiming that "no mesmeric act on earth will have anyone perform an act against their moral temper," and pretending to liberate Maggs from his "Phantom,". Oates is in fact itching to purloin his subject's story for a groundbreaking study of the Criminal Mind. His

\section{5}

Journal of Arabic Studies in Education \& Psychology ( ASEP ) 
true motives are commercial and his commitment is for selfserving. From the very beginning, Oates seeks to impose his mesmeric force on Maggs and the latter resists a forfeiture of will. With each session of hypnotism, their relationship grows increasingly deceptive and exploitative. One of the first things Maggs notices about Oates is his drive to dominate: "He was edgy, almost pugnacious, with eyes and hands everywhere about him as if he were constantly confirming his position in the world, a navigator measuring his distance from the chair, the wall, the table" (26).Hands, and the imagery associated with them, play an important role throughout Jack Maggs, as they do in Great Expectations (chapter 83). We learn for instance that when he set out to write about Maggs, Oates first produced a short essay on his hands, pondering . . . their history: what other hands they had caressed, what lives they had taken in anger. $\mathrm{He}$ began by picturing the newborn hand resting briefly on its mother's breast, and then he sketched, in the space of four pages, the whole long story leading towards and away from that 'hideously misshapen claw."' (303)

Thus, by contrast with Oates's hands, which figure as a visual correlative of manipulative power, Maggs's "hideously misshapen claw" is an index of his marginal status as an eccentric, or colonized subject.

Taking great pride in the essay referred to above, Oates "hoarded it like a clock-maker" and set it aside for "its small part in his grand machine" (303). These words clearly reveal Oates's problematic approach to his subject. According to Kaplan, Dickens was also "used to controlling and manipulating people, just as he was used to creating and manipulating characters in fiction"(72). But whereas he used his immense power of will "for what he assumed were beneficial and therapeutic ends" (237), Oates, while

\section{6}

Journal of Arabic Studies in Education \& Psychology ( ASEP ) 
professing the same ends, is in effect misusing this power.For one thing, he is turning mesmerism into a stage show, an "Exhibition," to which he invites his wife, his sister-in-law, Buckle, Constable, actor Henry Hawthorne, etc., who subject Maggs to intense scrutiny. Earlier, after the dinner at Buckle's house, when Maggs pressed Constable to describe what the guests had seen and heard, Constable replied: "You were a great turn, Mr. Maggs. You were a great thrill for the gentlemen" (31). Pinned by their gaze, Maggs becomes an object of curiosity and entertainment. Lizzie, on the other hand, is genuinely moved by the indelible marks of suffering written all over Maggs's body: "As Lizzie Warriner raised her eyes, she gasped at the sea of pain etched upon the footman's back, a brooding sea of scars, of ripped and tortured skin" (86).

"[P] ushing into the musty corridors of the Criminal Mind" at first gives Oates an exhilarating sense of discovery (91). The mesmerist believes he is in the possession of "a memory" that, like a "treasure house," he can "enters, and leaves. Leave and then return to." Oates's notion of memory reminds one of a passage from The Confessions, where Augustine puts forth what James Olney calls an "archeological model for memory": "When I am in this treasure house," Augustine writes, "I ask for whatever I like to be brought out to me, and then some things are produced atonce, some things take longer, and have, as it were, to be fetched from a more remote part of the store" (qtd. in Olney 19-20). Oates, too, sees himself as an "archeologist" of Maggs's mind, digging down through layer after layer of memories to unlock his mystery. "You can hear the cantin his talk," he tells Buckle. "He has it cloaked in livery but he wears the hallmarks of New South Wales." Buckle, however, feels that this sweeping characterization is unjustified : "We do ourselves no credit in judging him"

\section{7}

Journal of Arabic Studies in Education \& Psychology ( ASEP ) 
(87). Instead of empathizing with Maggs and his plight, Oates insists that Maggs is "a scoundrel" (87), or, to quote Bradley, "a symbol of demonic energy, of colonial wickedness, and perfidy. In this, Oates's attitudes to the real-world Maggs are similar to Dickens's fictional intentions for Magwitch" (3). To the extent that he sees what he wants to see, projecting his own fears and anxiety upon Maggs, Oates appears to be locked in the same ideological position vis-à-vis Australian convicts as Dickens.

As Maggs initially perceives him, Oates is "like a botanist" battling the demons that swim in his [Maggs's] "Mesmeric Fluid" and then describing them in his journal. Maggs is haunted not only by memories of an aborted child and a dying lover, but also by a vicious "Phantom," a nightmare self that, as Oates in the end reluctantly admits, "was his own invention, a personification of pain that he had planted in the other" (203). Indeed, through mesmerism, Oates partly revives and partly inflicts the terror of the past. That wretched past has become a living part of the present, freighted with gruesome revelations of whippings with the "double -cat," the brutality of the military guards, and the distrust between prisoners. When Oates rather condescendingly informs Maggs about the method he used to cue his memories, Maggs protests that, "Whatever it is called, it is a terrible thing, Sir, for a man to feel his insides all exposed to public view" (46). By the end of the novel, Oates, who has been desperately hiding secrets of his own, comes himself to fear that "he had done something against the natural order, had unleashed demons he had no understanding of, disturbed some dark and dreadful nest of vermin" (203).

In both Oates and Maggs, the fear of exposure creates the necessity for performance. "A fierce gent about his

\section{8}

J ournal of Arabic Studies in Education \& Psychology ( ASEP ) 
reputation," as Buckle describes him, Oates plays up his role of a faithful husband, responsible father, and dutiful reporter. But Oates is also a "fine actor" in that he demonstrates "a great talent for all kinds of dialects and voices, tricks, conjuring, disappearing cards, pantomime performances" (83). Both Maggs and Oates resort to disguises to further their ends, the first passing himself off as a footman, the latter as a physician who has come to quarantine Buckle's house because there is "contagion" in it (145). To Maggs, "this doctor" cuts an "incredible, ridiculous" figure, "with his twisted red mouth and wild bright eyes," and yet he exists "given life by some violent magic in his creator's heart" (146). Oates's threats and talk of "Mesmeric Fluid" cause the death of Mr. Spinks, Buckle's butler. The unfortunate incident functions as a reality check for Oates, whose life now begins to unravel (182). Having gained a measure of self-perspective, he reflects that his "fun and games had killed a man" (184). But by the end of the novel, Oates is, at least indirectly, responsible for three other deaths: the Thief-taker's, Lizzie's, and, in the final pages of his own novel, that of Maggs.

By arranging the convict's meeting with Wilfred Partridge, the Thief-taker who turns out to be a ruthless charlatan, Oates is unwittingly driving Maggs to commit murder. Once Maggs's violent tendencies are unleashed, the bala nce of power tips in his favor, causing his companion to become "almost neurasthenically aware of his force, his heat, his potential for further violence" (257). Fear overtakes the writer, as he realizes the compromising situation he put himself in:

If Jack were guilty of murder, Toby was guilty of being his accessory; if Jack were a bolter, it was Toby who had knowingly, criminally, harbored him. Of course he was a

\section{9}

Journal of Arabic Studies in Education \& Psychology ( ASEP ) 
man of letters but he had been a Fleet Street hack himself and knew that, once he was in the dock, the Press would feast no less greedily on one of their own. He did not need to consider the explosive secrets Jack Maggs might add to this conflagration. (257)

This passage brings into focus what James Eli Adams has called "the Victorian obsession with secrecy" and, implicitly, the "acute Victorian unease with strangers" (13). Both Maggs's outward appearance and his interiority, because they seem to defy, or subvert, traditional economic and social norms, arouse in the other characters (Buckle and Oates, in particular) suspicion of hidden designs. Carey follows Dickens and Carlyle in suggesting that, "secrecy is not merely a social strategy but an ontological condition" (Adams 58). Secrecy is generated by, and in turn, sustains, a pervasive dynamic of surveillance. Twice in the narrative, Maggs insists on exchanging secrets, first with Edward Constable, and later with Oates. As he explains to his fellow footman, the value of secrets resides in the balance of power they establish between those who exchange them. This is the lesson he learned in the penal settlements of the New South Wales:

There a man might be killed on account of knowing another man's secrets . . . every man would be a spy on every other man. It was how they kept us down. If you and I were lads together in that place, then you must give me a secret of yours, should you chance to stumble over one of mine. That way we were in balance. (169)

Because the compromising secrets that Oates wrested from Maggs under false pretenses have upset the balance, Oates has to reveal a "very bad secret" of his own-his love affair with Lizzie and the pregnancy that threatens to expose them (233).

\section{0}

J ournal of Arabic Studies in Education \& Psychology ( ASEP ) 
The novelist makes no secret of his obsession with others' lives, but he himself is terrified that others might ruffle the paradise of fulfillment he has so carefully constructed for himself and his family. At the same time, though, as Nicholas Jose has remarked, "In satisfying his craving for money, love and recognition," Oates "unravels himself too-as the writer of fiction spins invention from his own guts." Indeed, the intensity of Oates's relationship with Maggs threatens to disturb the equilibrium of the writer's self in the present, marking as "crucial" a step in "the process of self-discovery" as Dickens's experience with Madame de la Rue apparently did (Kaplan 106). Like Dickens, Oates fights out his own emotional battles by way of the struggles of his patient/character, but refuses to take a step further, as it were, and reach out to Maggs in real life. The extent of his sympathy for Maggs does not go beyond an unfulfilled promise :

I wrote down what you told me in your sleep, Jack. One day you will read every word of it. Every dream and memory in your head, I'll give them to you, I promise. You have had a hard life, my friend, and more than your fair share of woe. I would never make light of your misfortune. (265)

Maggs, however, comes to doubt the writer's intentions, particularly after he discovers that the latter has fabricated the transcriptions of their meetings in order to "hide the true nature of his exploration" (91). One of the most intriguing scenes about writing occurs in the coach to Gloucester, in chapter 62, where Oates takes out his portmanteau and begins to compose the first chapter of his planned novel. When Maggs asks to see his notes, Oates reads out loud a sketch about "The Canary Woman," an old eccentric famous for amusing "the family of the King and Queen" (226). Oates, whose heart is "beating very fast,"

\section{1}

J ournal of Arabic Studies in Education \& Psychology ( ASEP ) 
insists that this "comic figure" is not Maggs, but then, since "To the Gods we are all comic figures," he adds: "If you could look on my life from on high, you would split your sides to see the muddle I am making of it" (227). In making this confession, Oates hopes to pacify Maggs and elicit his sympathy for flaws and limitations that he, the writer, arguably shares with all of his characters. Apart from revealing the writer's penchant for self-dramatization, the statement also brings to mind Dickens's letter to Foster in which he mentions the "grotesque tragic -comic conception" that first encouraged him to write Great Expectations (734). In Jack Maggs, the tragic lies beneath the comic surface, and sometimes breaks through, but, in the light of the tender ending that Carey has prepared for Maggs, the novel foregrounds adaptability and vitality as prime conditions for the survival of man as a civilized animal.

Maggs's tale of survival falls on deaf ears, as it were, provoking anger mixed with envy in Oates: "To think this criminal should own a lease while he should be forced to waste his time on Comic Romps and Brighton fires" (228). Throughout Jack Maggs, ownership - the ownership of property, of one's past, and, implicitly, of one's identity emerges as an important motif, linked suggestively to the image of the writer as burglar, who sees his character as a commodity, a "treasure house" to plunder at will. "You are a thief," Maggs reproaches Oates; "You have cheated me, Toby, as bad as I was ever cheated" $(279,281)$. Infuriated by the novelist's deceptive practice, Maggs forces the "transgressor" to burn the early drafts and the chapbook. This episode takes on a special significance once we learn that a short time before he began to write Great Expectations, Dickens made two bonfires of his personal letters and also re-read David Copperfield, perhaps the most overtly autobiographical of all of his novels. Smith has

\section{2}

J ournal of Arabic Studies in Education \& Psychology ( ASEP ) 
interpreted the episode as a "central suppression" motivated by Dickens's stated need to conceal details of his private life "with which he had become dissatisfied" (44). According to Lettis, "Dickens greatly disliked the pursuit of literature through study of the lives of its authors," and therefore burned the letters "to cut off any such indirect study of his work" (4). His message was that a writer's life is personal property, irrelevant to an understanding of his work.

Much like Dickens/Oates, Maggs regards his own life as personal property, relevant insofar as he tells its story himself. Although we do not actually see Oates destroy any personal correspondence, the close relationship he develops with his subject, as well as his method of creating characters through imaginative transposition, suggests that the manuscripts he burns do carry a strong, albeit suppressed, personal meaning. The writer's task is somehow eased by the fact that, having experienced the power-physical and mental - that Maggs possesses, he "lost interest in his subject: the Criminal Mind had become repulsive to his own imagination" (303). If later Oates "mourned the manuscripts he then so readily destroyed" it is because he "forgot how badly he had wanted Maggs gone from his life" (304).

Grief-stricken at the loss of Lizzie, his dream of love dispelled, Oates cannot resist heaping up "all his blame" upon Maggs: "It was now . . . in the darkest night of his life, that Jack Maggs began to take the form the world would later know. This Jack Maggs was, of course, a fiction" (326). On this fictional level, Oates succeeds where Henry Phipps fails, for the apocalyptic scene he envisions as the climax to his novel portrays Maggs as a demonical figure consumed by flames, "flowering, threatening, poisoning," and hopping "like a devil" (326). As already seen, on yet

\section{3}

J ournal of Arabic Studies in Education \& Psychology (ASEP ) 
another fictional level, the ending that Carey gives Maggs affords the consolation of romance, with Maggs marrying the woman who helped him recognize the claims of his Australian sons "to have a father kiss them good night." "There is no character like Mercy in The Death of Maggs," the narrator tells us. Whereas the first ending projects the violence and deep anxiety that attend colonization, the second "manages to reverse cathartically" this process, "the colony in a very real sense reclaiming its history from its imperial master" (Bradle y 4).

Carey's postcolonial revisioning of Great Expectations rises successfully to the challenge and heights of Dickens's major work of the 1850s and 1860s. Their common feature is a poignant criticism of Victorian society, which goes deep enough to be a universal criticism of human nature. Written with wit, style, and deep feeling, the novel bears out Carey's mastery as a storyteller acutely sensitive to the fragility of truth and the unreliability of memory. This is because our vision of the "real" world often hinges on what bring to it not only from past "reality" but also from the world of fiction or imagination. For Dickens, too, art is a distillation of the actual, just as memory is a distillation of the past, of those "saving spots of time" which nourish one's imaginative capacities. As Lettis put it, "Dickens looks at reality like a modern painter: what he sees is not just what is there, but $[\ldots]$ something more, something seen when one mixes memory and desire..." (190). It is important to stress that Dickens did not see such an effort as a distortion of reality, but as an interpretation of it.

The inventive energy of language and situation in Jack Maggs, masks but does not displace, the anxiety about the hazards of imaginative life, more specifically, about the role of narratives in understanding and conveying trauma. By

\section{4}

J ournal of Arabic Studies in Education \& Psychology ( ASEP ) 
turns comic, sad, and nightmarish, Jack Maggs follows its protagonist's dramatic journey in search of a place he can call home; through the "mutually reflexive acts of narrative and memory" (Olney xiv), home is redefined as both a point of departure and a point of return. The trajectory of Maggs's life intersects with that of novelist Tobias Oates, another strong-willed figure whose "crooked business," and the mind behind it, Carey investigates in an attempt to explain the birth of a book (Great Expectations) and the death of a character (Abel Magwitch).

Doubtless, the novel offers no conventional portrait of the artist as a young man. Since the author makes no claim to a "real life" basis for representation, Oates's portrait surprises, amuses, and provokes his readers. As a selfreflexive exercise in invention, Jack Maggs develops a great number of definitions for the writer: a storyteller, an archeologist of the mind, a mesmerist, magician, craftsman, and last, but not least, a "thief." To be a writer, Carey implies, is to have one's feet in both worlds - the public and the private, the actual and the imaginary, the material and the intellectual. Oates's professional life in the marketplace shapes his daily creative labours, which in turn reflect his desire to simultaneously confront and escape life's harsh realities.

Oates is, like Maggs, a restless soul hungry for love, but ultimately incapable of committing himself with heart and soul to anyone. He therefore reserves little sympathy for Maggs, who interests him more as a case study, than as a human being who embodies the dual capacities of man for good and evil. Maggs's "demons" originate not in the penal colonies, but in the very heart of the empire, which is London. Oates's excursion into the depths of Maggs's psyche leads him to proclaim "the horror" of the other, rather than the "saving illusion" of tolerance and compassion.

\section{5}

Journal of Arabic Studies in Education \& Psychology ( ASEP ) 
The analysis offered has led the researcher to a tantalizing conclusion: in reprising the past with a difference, postmodernism has also reappraised it so as to make it a precedent. Carey as a late twentieth-century writer has seized on the legacy of a canonical author to legitimize the origins of postmodernism, but in doing so he has also succeeded - through cultural revisionism - in making that origin a source of his own originality. This technique allows us to see how postmodernism and the preceding "isms" illuminate one another's forms, aesthetic strategies, cultural logics, or continued relevancies.From a broader perspective, the re-readings, revisions, and reevaluations take their place in the ongoing process of historicizing postmodernism.

\section{WORKS CITED}

Ackroyd, Peter. Chatterton. New York: Grove P, 1987.

Adams, James Eli. Dandies and Dessert Saints. Styles of Victorian Manhood.Ithacaand London: Cornell UP, 1995.

Allen, David. Modest Expectations, a play. New York: Harper \& Row, 1990.

Atwood, Margaret. Negotiating with the Dead. A Writer on Writing. Cambridge: CUP, 2002.

Barnes, Julian. Flaubert's Parrot. New York: McGraw-Hill, 1984.

Bayley, John. The Uses of Division: Unity and Disharmony in Literature. New York: Viking P, 1976.

Bowen, John. Other Dickens: Pickwick to Chuzzlewit. Oxford: Oxford UP, 2000.

Bradbury, Nicola. "Dickens and the Form of the Novel." John O. Jordan. 152-67

Bradley, James. "Bread and Sirkuses: Empire and Culture in Peter Carey's The Unusual Life of

Tristan Smith and Jack Maggs." Meanjin . 56.3/4 (1997): 6pp. Academic Search Elite.UNCG Library. 12 April 2003.

<http://search.epnet.com/direct.asp?an=313873\&db=afh.> Bush, Frederick. The Mutual Friend. New York: Routledge , 1978

Carey, Peter. Jack Maggs. London \& Boston: faber \& faber, 1997.

---. Interview with Ramona Koval. "The Unexamined Life." Meanjin. 56.3/4 (1997): 9pp.

Academic Search Elite. 12 April 2003._<http://search

\section{6}

J ournal of Arabic Studies in Education \& Psychology ( ASEP ) 
.epnet.com/direct.asp?an=313876\&db=afh>.

Cheadle, Brian."Dispatched to the Periphery: The Changing Play of Center and Periphery

in Dickens's Work." Sadrin. 100-112.

Crunden Robert M. American Salons: Encounters with European Modernism, 1885-1917. New York: Oxford UP, 1993. Deane, Bradley. The Making of the Victorian Novelist: Anxieties of Authorship in The Mass Market. New York: Routledge, 2003.

Dickens, Charles. A Tale of Two Cities. Philadelphia: Running $\mathrm{P}, 1992$

--- Great Expectations. Philadelphia: Running P, 1992

Elias, Amy J. Sublime Desire. History and Post-1960 Fiction. Baltimore: The Johns Hopkins UP, 2001.

Faulkner, William. The English Modernist Reader: 1910-1930. Iowa City: U of Iowa P, 1986

Forster, John. The Life of Charles Dickens. 2 vols. London: J.M. Dent \& Sons, 1948.

Hassall, Anthony J. "A Tale of Two Countries: Jack Maggs and Peter Carey's Fiction." Australian Literary Studies. 18.2 (Oct. 1997): 8pp. Academic Search Elite. 12 April http://search.epnet.com/direct.asp?an=9712050959\&db=afh

Holmes, Richard. Sidetracks: Explorations of a Romantic Biographer. New York: Pantheon Books, 2000.

Hughes, Robert. The Fatal Shore. Sydney: Pan Macmillan, 1988.

Jordan, John O, ed. The Cambridge Companion to Charles Dickens. Cambridge : CUP, 2001.

Kaplan, Louise J,. The Family Romance of the Impostor-Poet Thomas Chatterton. New York: Atheneum, 1988.

Lettis, Richard. Dickens on Literature. A Continuing Study of his Aesthetic. New York: AMS P, 1990.

NaiPaul, V.S. A House for Mr Biswas. Boston: Twayane P.1961.

Olney, James. Memory and Narrative: The Weave of LifeWriting. Chicago: U of Chicago P, 1998

Pierce, Peter. The Country of Lost Children: an Australian Anxiety. Cambridge \&New York: CUP, 1999

Rushdie, Salman. Satanic Verses. New York: Viking, 1989.

Smith, Grahame. "Suppressing Narratives: Childhood and Empire in The Uncommercial Traveller and Great Expectations." Dickens and the Children of Empire. Ed. Wendy S. Jacobson. New York: Palgrave, 2000.

Steiner, George. Grammars of Creation. New Haven and London: Yale UP, 2001

\section{Abbreviations}

LC2 Henry James: Literary Criticism. Vol. II

\section{7}

